\title{
DERMAL CONNECTIVE TISSUE PERMEABILITY IN RHEUMATOID ARTHRITICS*
}

\author{
BY \\ A. HERP, J. FABIANEK, A. CALICK, AND W. PIGMAN \\ From the Department of Biochemistry, New York Medical College, New York, N.Y., 10029, U.S.A.
}

Previous studies indicate that the transfer of proteins and other substances between synovial fluid and blood is more extensive for rheumatoid arthritics than for normal persons (Harris, Millard, and Banerjee, 1958; Platt, Holley, and Pigman, 1957; Michelazzi, 1943). The protein concentration in synovial fluid is also higher for rheumatoid arthritics than for healthy individuals (Platt and others, 1957; Decker, McKenzie, McGuckin, and Slocumb, 1959; Johansen and Sylvest, 1961). These alterations suggest that a feature of this disease may be an enhanced permeability of the connective tissue. The altered permeability, in turn, could arise from a change of the physical state of the ground substance of connective tissue, particularly of the hyaluronic acid, which is especially important for the physical properties of the ground substance. This concept is in agreement with the observations that the degree of polymerization of hyaluronic acid is decreased in the synovial fluid of patients with connective tissue disease (Ragan and Meyer, 1949; Sundblad, 1953; Bollet, 1956; Stafford, Niedermeier, Holley, and Pigman, 1964), since the synovial fluid is probably derived from the ground substance.

This laboratory has been engaged for some time in studying the nature of the oxidative-reductive depolymerization (ORD-reaction) of hyaluronic acid by autoxidants and the relation of this reaction to catabolic processes (Pigman, Matsumura, and Herp, 1965). Several autoxidants and antioxidants (inhibitors) which affected the in vitro oxidative-reductive depolymerization of hyaluronic acid (Pigman, Rizvi, and Holley, 1961; Pigman and Rizvi, 1959) were also found to affect in vivo skin permeability (Fabianek, Herp, and Pigman, 1963; 1965).

The present paper reports data on a study of the

*This work was supported by a grant from the National Institutes of Health (AM-04619). "permeability" of human skin for groups of healthy subjects, hospitalized non-arthritic patients, and rheumatoid arthritic patients. Since most of the arthritics were on medication at the time of experimentation, the effect of oral ingestion of aspirin and other inhibitors on the skin "permeability" of rats was also investigated.

\section{Methods and Material}

Methods.-Connective tissue permeability was tested in vivo by two methods: one measured the rate of intradermal diffusion of dye (spreading method), (DuranReynals, 1935; 1936) and the other was based on the subdermal infusion rate of physiological saline (infusion method), (Lenstrup, 1951).

Spreading Method.-0.05 ml. Evans blue dye dissolved in saline was injected intradermally into the shaved abdominal region of rats or the upper thigh area of humans, three to six injections being applied to each subject. The spot contours were traced on to transparent paper $30,60,120$, and 180 minutes after the injections. The traced areas were cut out, weighed, and converted to surface areas as mm. ${ }^{2}$

Infusion Method.-This was used only for the rats; it measured the flow rate of a subcutaneous infusion at constant pressure, of saline alone and after injection of $0.5 \mathrm{ml}$. of a 0.1 per cent. solution of $L$-ascorbic acid. The ratio between the volume of saline that was absorbed after the injection of test compound (ascorbic acid in the present study) to the volume of saline absorbed during the same period of time before the injection of the test compound is taken as the criterion of permeability. A detailed description of these methods has been published elsewhere (Fabianek and others, 1963).

\section{Material}

Human Subjects. - Three groups of Caucasian human subjects were used. Group I were medical students and nurses of 20 to 24 years of age, free of any pathological symptoms.

Group II consisted of hospitalized non-arthritic patients most of whom were being treated for fractures. 
Group III consisted of hospitalized patients with rheumatoid arthritis, who satisfied the criteria of the disease as established by the American Rheumatism Association (Ropes, Bennett, Cobb, Jacox, and Jessar, 1957). The stage and activity of the disease as well as the medication at the time of the study are listed in Table I.

Each of the three groups included both males and females. The age distribution of Groups II and III were similar; but the ages varied from 16 to 86 years. The spreading method, as described above, was used for all subjects, the site of injection being the exterior lateral region of each thigh; three to six injections of Evans blue solution were given to each person.

Animal Experiments.-80- to 100-day-old male and female rats of the CFE strain (purchased from Carworth, Inc., New City, N.Y.) were divided into groups of ten to twelve animals. Those which were treated with ethanol received the substance ad lib. as a 10 per cent. solution in place of drinking water. The rats of the other groups received a daily oral dose of one of the substances listed in
Table III at the dosage indicated. The compounds were dissolved or suspended in $2 \mathrm{ml}$. water* and administered므. via esophageal intubation for 18 days. Prednisone, administered orally as aqueous suspension, was also $\vec{\Rightarrow}$ examined for its short-term effect. The animals were? then anaesthetized and tested for skin "permeability" by? one or both methods described above. The average body음 weights for each group, measured at the beginning andos end of the experimental periods, are noted in Table IIIه (below page 349).

\section{Results}

The results of the application of the spreading testw to healthy humans and rheumatoid arthritics are given in Table II. The spread area was recorded asō $\mathrm{mm} .^{2}$ at intervals of $30,60,120$, and 180 or $240 \mathrm{~N}$

* In the case of cysteine the $\mathrm{pH}$ of the aqueous solution was adjusted $\mathrm{f}$ to about 6.

TABLE I

STATUS OF RHEUMATOID ARTHRITIC PATIENTS

\begin{tabular}{|c|c|c|c|c|c|}
\hline $\begin{array}{c}\text { Patient } \\
\text { No. }\end{array}$ & $\begin{array}{c}\text { Age } \\
\text { (yrs) }\end{array}$ & Sex & $\begin{array}{c}\text { A.R.A. } \\
\text { Classification }\end{array}$ & $\begin{array}{l}\text { Disease } \\
\text { Activity }\end{array}$ & Medication \\
\hline $\begin{array}{r}1 \\
2 \\
3 \\
4 \\
5 \\
6 \\
7 \\
8 \\
9 \\
10 \\
11 \\
12 \\
13 \\
14 \\
15 \\
16 \\
17 \\
18 \\
19\end{array}$ & $\begin{array}{l}75 \\
39 \\
45 \\
48 \\
57 \\
75 \\
43 \\
48 \\
25 \\
20 \\
16 \\
69 \\
71 \\
50 \\
69 \\
40 \\
19 \\
61 \\
56\end{array}$ & $\begin{array}{l}\mathbf{F} \\
\mathbf{F} \\
\mathbf{F} \\
\mathbf{F} \\
\mathbf{F} \\
\mathbf{F} \\
\mathbf{F} \\
\mathbf{F} \\
\mathbf{F} \\
\mathbf{F} \\
\mathbf{M} \\
\mathbf{M} \\
\mathbf{M} \\
\mathbf{M} \\
\mathbf{M} \\
\mathbf{M} \\
\mathbf{M}\end{array}$ & $\begin{array}{l}+++ \\
++ \\
+ \\
+++ \\
+++ \\
++ \\
++ \\
+++ \\
\text { L.E. } \\
\text { L.E. } \\
\text { L.E. Iron deficiency } \\
+++ \\
+++ \\
++ \\
+++ \\
\\
++ \\
+\end{array}$ & $\begin{array}{l}++ \\
++ \\
+ \\
+++ \\
+ \\
++++ \\
++ \\
++ \\
\\
+ \\
+ \\
+ \\
+ \\
++ \\
++\end{array}$ & $\begin{array}{l}\text { NPH,(1) Darvon(2) } \\
\text { Darvon, Thorazine } \\
\text { Gamma-globulin } \\
\text { Penicillamine } \\
\text { Aspirin, Prednisone } \\
\text { Penicillamine } \\
\text { None } \\
\text { Aspirin, Prednisone } \\
\text { Prednisone } \\
\text { Isoniazid( (4) } \\
\text { Prednisone } \\
\text { Mercuhydrin } \\
\text { Digitalis } \\
\text { None } \\
\text { None } \\
\text { Prednisone } \\
\text { Aspirin } \\
\text { Prednisone } \\
\text { Prednisone }\end{array}$ \\
\hline
\end{tabular}

(1) Isophane insulin. (2) D-Propoxyphene HC1. (3) 2-Chloro-10-phenothiazine. (4) Isonicotinic acid hydrazide.

TABLE II

SUMMARY OF RESULTS OBTAINED WITH SPREADING METHOD* IN HUMAN SUBJECTS

\begin{tabular}{|c|c|c|c|c|c|c|c|c|c|c|c|}
\hline \multirow{2}{*}{\multicolumn{2}{|c|}{ Group }} & \multirow{2}{*}{$\begin{array}{c}\text { Number } \\
\text { of } \\
\text { Cases }\end{array}$} & \multirow{2}{*}{ Sex } & \multicolumn{2}{|c|}{ Age (yrs) } & \multirow{2}{*}{$\begin{array}{c}\text { Number } \\
\text { of } \\
\text { Spots }\end{array}$} & \multicolumn{5}{|c|}{ Spot Area $\left(\mathrm{mm} .{ }^{2}\right)$ after } \\
\hline & & & & Range & Average & & $30 \mathrm{~min}$. & $60 \mathrm{~min}$. & $120 \mathrm{~min}$. & $180 \mathrm{~min}$. & $240 \mathrm{~min}$. \\
\hline \multirow[t]{2}{*}{ I } & \multirow[t]{2}{*}{ Students and Nurses } & $\begin{array}{r}17 \\
8\end{array}$ & $\begin{array}{l}\mathbf{M} \\
\mathbf{F}\end{array}$ & $\begin{array}{l}20-24 \\
20-24\end{array}$ & $\begin{array}{l}23 \\
22\end{array}$ & $\begin{array}{l}49 \\
20\end{array}$ & $\begin{array}{l}67 \pm 15 \\
65 \pm 18\end{array}$ & & $\begin{array}{l}86 \pm 16 \\
81 \pm 20\end{array}$ & & $\begin{array}{l}110 \pm 20 \\
102 \pm 28\end{array}$ \\
\hline & & 25 & $\mathbf{M}+\mathbf{F}$ & & & 69 & $66 \pm 18$ & & $84 \pm 22$ & & $108 \pm 25$ \\
\hline \multirow[t]{2}{*}{ II } & \multirow[t]{2}{*}{$\begin{array}{l}\text { Non-arthritic } \\
\text { Hospitalized Patients }\end{array}$} & $\begin{array}{r}11 \\
8\end{array}$ & $\begin{array}{l}\mathbf{M} \\
\mathbf{F}\end{array}$ & $\begin{array}{l}20-53 \\
59-86\end{array}$ & $\begin{array}{l}40 \\
65\end{array}$ & $\begin{array}{l}52 \\
48\end{array}$ & $\begin{array}{l}63 \pm 15 \\
59 \pm 17\end{array}$ & $\begin{array}{l}68 \pm 15 \\
64 \pm 14\end{array}$ & $\begin{array}{l}82 \pm 17 \\
78 \pm 21\end{array}$ & $\begin{array}{l}92 \pm 17 \\
91 \pm 20\end{array}$ & \\
\hline & & 19 & $\mathbf{M}+\mathbf{F}$ & & & 100 & $61: t 18$ & $66 \pm 16$ & $80 \pm 2 . ?$ & $91 \pm 22$ & \\
\hline \multirow[t]{2}{*}{ III } & \multirow[t]{2}{*}{$\begin{array}{l}\text { Rheumatoid Arthritics } \\
\text { Lupus Erythematosus }\end{array}$} & $\begin{array}{l}8 \\
8 \\
3 \\
\end{array}$ & $\begin{array}{l}\mathbf{M} \\
\mathbf{F} \\
\mathbf{F}\end{array}$ & $\begin{array}{l}19-71 \\
39-67 \\
16-25\end{array}$ & $\begin{array}{l}54 \\
54 \\
22\end{array}$ & $\begin{array}{l}32 \\
36 \\
12 \\
\end{array}$ & $\begin{array}{l}78 \pm 18 \\
81 \pm 14 \\
79 \pm 9\end{array}$ & $\begin{array}{l}82 \pm 18 \\
87 \pm 15 \\
94 \pm 11\end{array}$ & $\begin{array}{r}99 \pm 23 \\
105 \pm 24 \\
101 \pm 10\end{array}$ & $\begin{array}{l}125 \pm 37 \\
116 \pm 27 \\
109 \pm 13\end{array}$ & \\
\hline & & 19 & $\mathbf{M}+\mathbf{F}$ & & & 80 & $80 \pm 13$ & $85 \pm 17$ & $102 \pm 20$ & $117: \pm 31$ & \\
\hline
\end{tabular}

* Evans blue (4 mg./ml.) was dissolved in saline and adjusted to pH 7.3;0.05 ml. of dye solution was injected intradermally. 
minutes after intradermal injection of the dye solution. The arthritic patients (Group III) showed a significantly enhanced spread area as compared to the individuals of the control Groups I and II; their spot area (and standard deviation) after 30 minutes averaged $80 \pm 13 \mathrm{~mm} .{ }^{2}$ compared to $66 \pm 18 \mathrm{~mm} .{ }^{2}$ for the students and nurses of Group I and $61 \pm 18 \mathrm{~mm} .^{2}$ for the non-arthritic hospitalized patients of Group II. Frequency distribution plots in the form of histograms of the individual spread areas recorded at the different time intervals for Groups II and III are given in Figs 1 and 2. The results obtained in Group II (hospitalized non-arthritics) showed an approximately normal distribution about the average. A similar distribution was obtained for the spot size in Group I. The distribution shown in Fig. 2 for the rheumatoid arthritics was, however, skew.
The rate of spreading of the individual spots for four individuals measured over $180 \mathrm{~min}$. is shown overleaf in Fig. 3 for rheumatoid arthritics and in Fig. 4 for non-arthritic hospitalized patients. A progressive increase of spot size with time was the general trend. The "normal" group showed less disperson than the rheumatoid group. Despite this variation, the averages showed consistently significant differences between the arthritic and normal groups.

With the co-operation of Bernard Carol, Director of the Computer Center of this institution, multiple comparison theory was applied to the various contrasts of averages of interest (Scheffé, 1959). The error rate considered the totality of statements as a unit; either all were correct simultaneously or the experiment was faulty. The standard error was

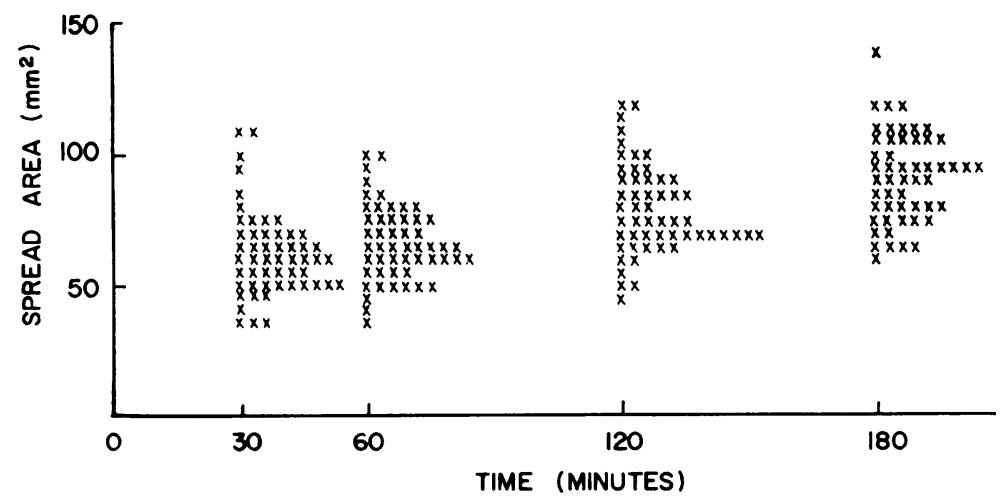

Fig. 1.-Distribution of individual spot areas (mm.2) for non-arthritic hospitalized patients.

Fig. 2.-Distribution of individual spot areas (mm. $\left.{ }^{2}\right)$ for rheumatoid arthritic hospitalized patients.

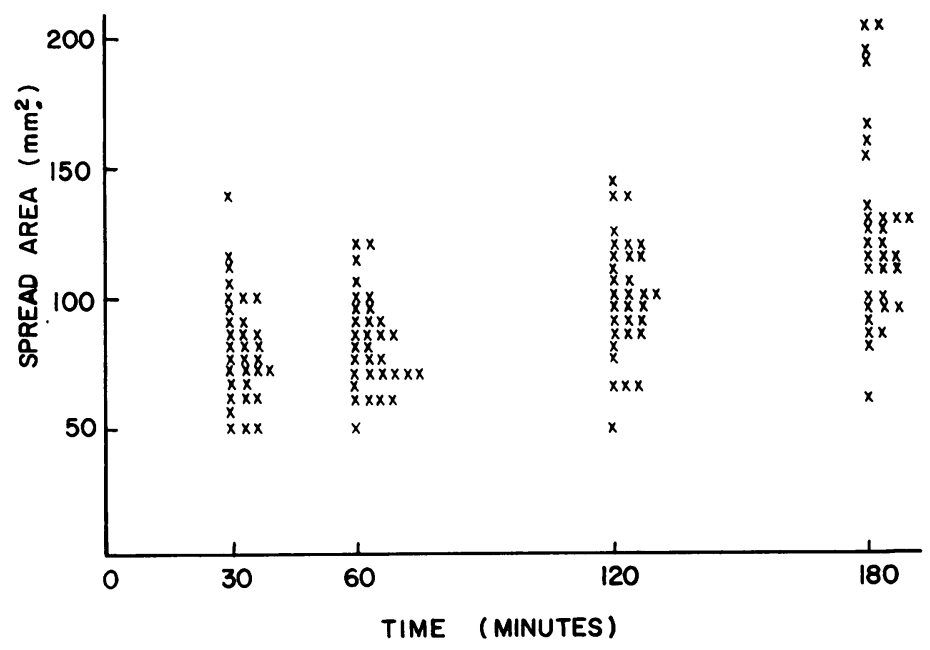




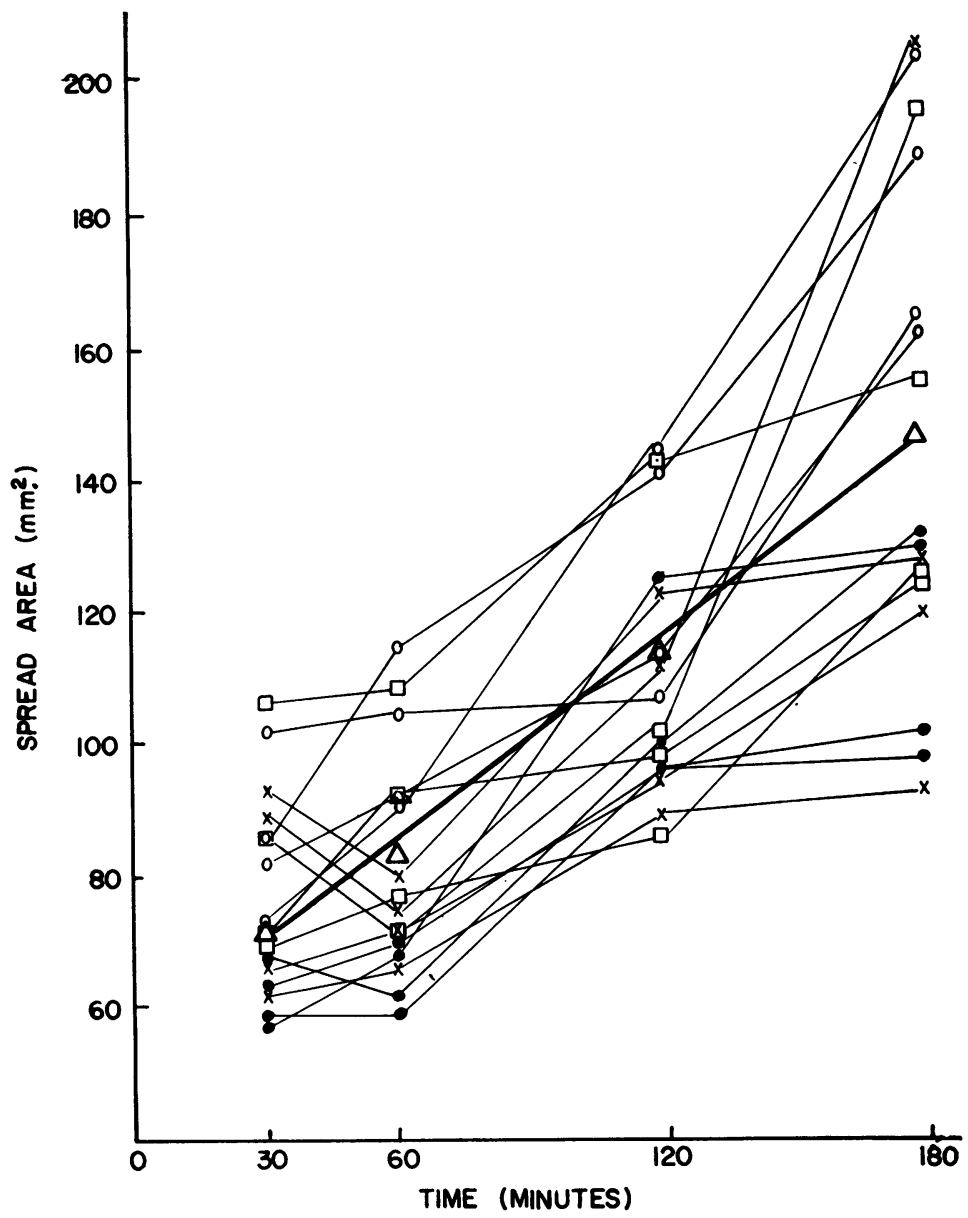

Fig. 3--Rate of spreading of individual spot areas of rheumatoid arthritic male patients (4 subjects)

based on the within persons sum of squares of a three-way analysis of covariance. Time was used as a linear concommitant variable.

Arthritics (Group III) compared both with nonarthritic patients alone (Group II) and with students and non-arthritics together (Groups I and II) showed significantly greater permeability at the $\mathbf{0 . 1}$ per cent. level. A further breakdown by sex showed differences of the same significance and direction between arthritics and non-arthritics for males and females separately in each group. In contrast, no significant differences were found between male and female subjects of Groups I and II. When arthritics below 50 years of age were compared with older arthritic patients, a difference significant at the 0.1 per cent. level was observed in favour of the aged. For the non-arthritics the permeability was less for the older group and for the arthritics the reverse was true.

Table III (opposite) shows the effects on skino "permeability" in rats of the oral ingestion over 18 days of known inhibitors of the depolymeriza-o tion of hyaluronic acid in vitro (ORD reaction). This Table also includes the results of the oral adminis- -0 tration of the drugs which were most widely used as $N$ medication by the patients tested in this study. For the spreading method, the change in dermal perme- 0 ability produced by the injection of Evans blue alone in the treated rats was expressed as percentage difference compared with the control group. Table III@ shows only the data for the 30 -min. tracings in the spreading method, since the results for longer timeso gave essentially the same pattern. In the case of prednisone, the results given are those obtained for 


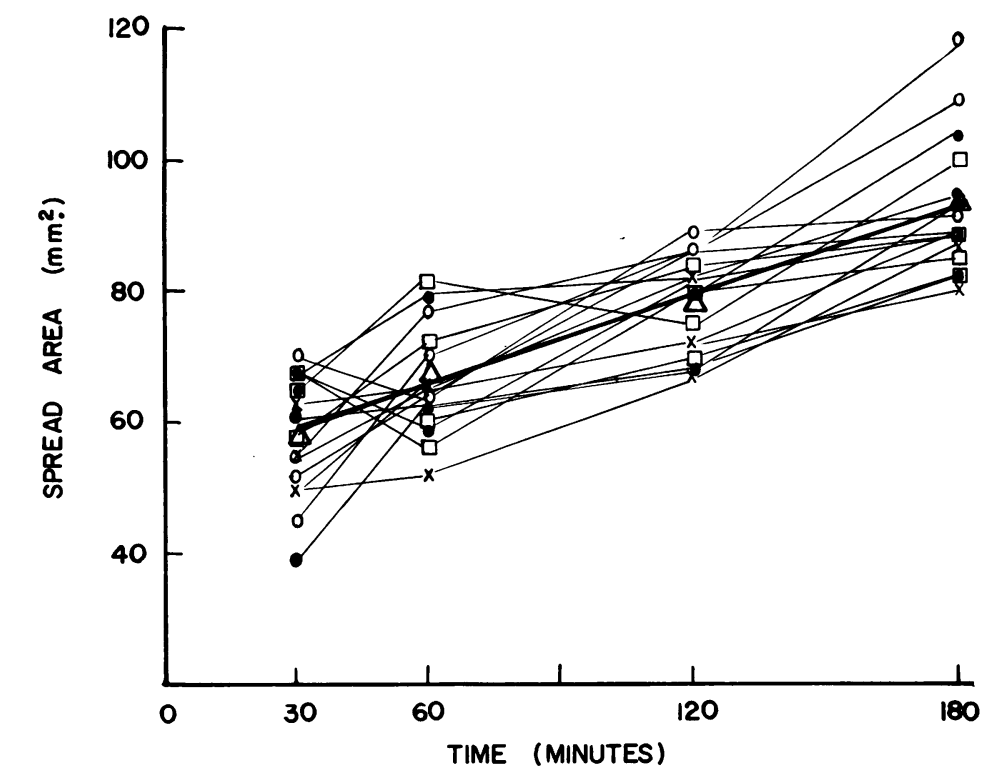

Fig. 4.- Rate of spreading of individual spot areas of non-arthritic hospitalized male patients (4 subjects).

TABLE III

EFFECT OF ORAL ADMINISTRATION OF ANTI-RHEUMATIC SUBSTANCES FOR 18 DAYS ON DERMAL "PERMEABILITY" IN RATS

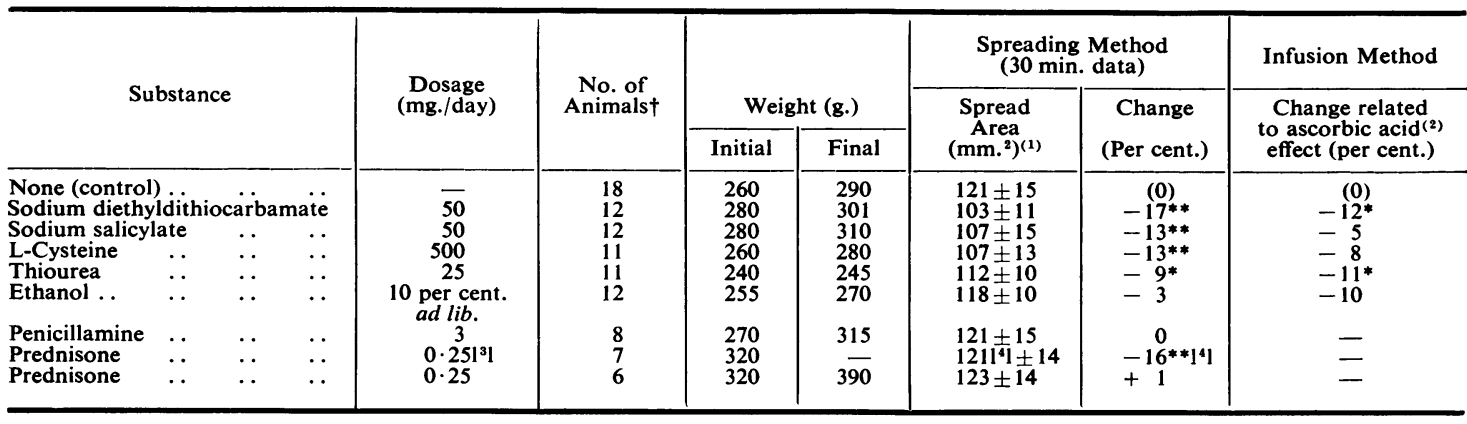

** $\mathrm{P}<0.01 . \quad{ }^{*} \mathrm{P}<0.05$ as compared to untreated rats (Student " $t$ " test). † Half males and half females.

(1) $0.05 \mathrm{ml}$. Evans blue in saline at pH 7.3; area measured after $30 \mathrm{~min}$.

(2) Ascorbic acid (1 mg./ml.) produced in untreated animals a permeability increase of 18 per cent.; this value was taken as control (0).

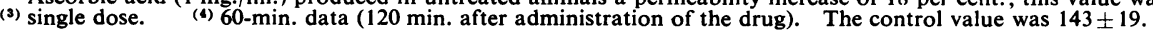

the 60-min. tracing, and must be compared with a different control.

For the infusion method, the permeability was tested, using L-ascorbic acid as the control substance in both treated and untreated animals. Thus, for this method, the results in Table III are the percentage change in permeability produced by ascorbic acid in treated animals as compared with that obtained with ascorbic acid in control (untreated) animals.

These inhibitors when ingested orally in rats usually caused a decrease in skin permeability as shown in Table III. As in the in vitro system, sodium diethyldithiocarbamate was the most active compound. The drugs used by some of the rheumatoid arthritics in this study (penicillamine, prednisone, and salicylates) either had no effect or also acted as inhibitors of skin permeability. More detailed information is given for prednisone in Fig. 5 (overleaf). When o given regularly for 3 weeks before the tests were $N$ made, it had no inhibitory action. However, when $\underset{\mathcal{N}}{N}$ a single dose was given just before the tests were made, it caused a marked inhibition of the permeability.

\section{Discussion}

In the present study, arthritic patients of both sexes showed larger areas of spread than individuals $\stackrel{\mathbb{}}{\stackrel{ }{\circ}}$ in the control groups after the intradermal injection $\mathbb{D}$ 


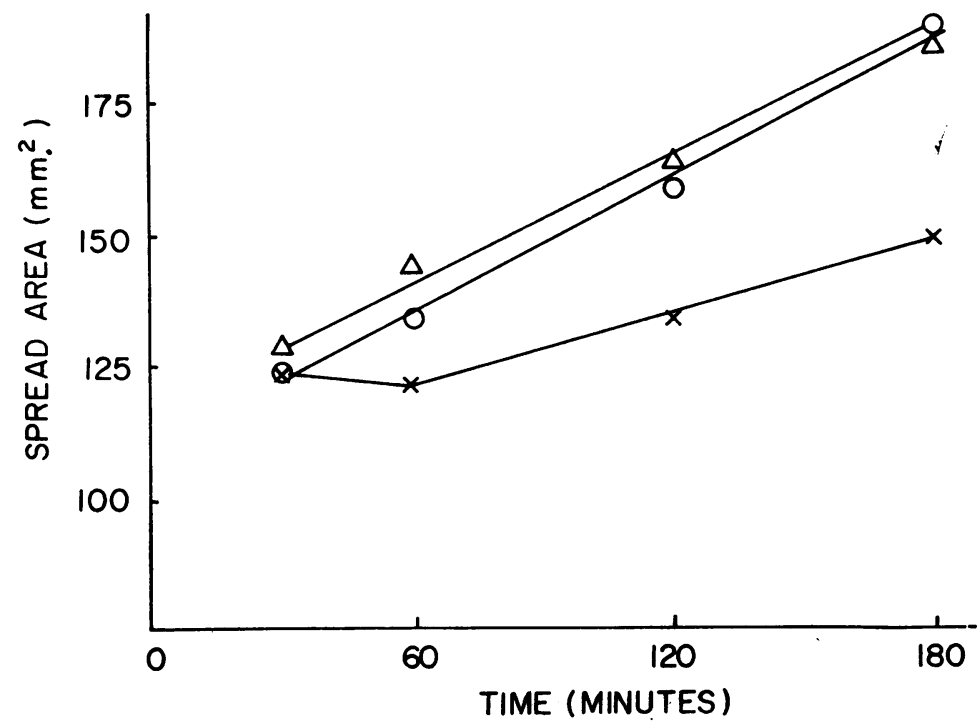

Fig. 5.-Effect of prednisone on skin permeability in male rats. $\triangle$ control animals;

of a solution of Evans blue dye. The rate of diffusion of the dye solution averaged 30 per cent. higher for the arthritic patients. A statistical evaluation, using multiple comparison theory, showed the differences to be significant at less than $0 \cdot 1$ per cent.

An increase of "permeability" with age found in rheumatoid arthritic patients is probably the result of the slow and progressive development of the disease. The non-arthritic subjects showed a decrease in permeability with increasing age.

Three female patients afflicted with lupus erythematosus and used in the present study (Cases 9-11) also showed increased skin "permeability" (Table II), but the number of subjects available was not sufficient to give this observation statistical significance.

Since most of the arthritic patients had been on various medications (Table I), the drugs used could be responsible for influencing the observed increase in "permeability". Earlier studies on animals in this laboratory, however, showed that anti-rheumatic drugs, such as gold chloride, aspirin, and sodium salicylate, were active locally as inhibitors of dermal connective tissue permeability in vivo (Fabianek and others, 1965). Similar observations in vitro have shown that salicylates, penicillamine, corticosteroids, and gold chloride have some inhibitory effect on the depolymerization of hyaluronic acid in vitro by ascorbic acid (Matsumura, Herp, and Pigman, in the press). In the present work the prolonged oral administration of the agents listed in Table III either caused a net inhibition of skin "permeability" as defined by the methods used or were inactive. $\vec{\bullet}$ Sodium diethyldithiocarbamate showed the strongest 8 inhibitory effect. This effect is in agreement with the results in vitro, which showed this compound to be the most active inhibitor of the ORD reaction (Pigman and others, 1961).

Cysteine at low concentration promoted the depolymerization of hyaluronic acid in vitro, but at high concentration it inhibited this same reaction $\overrightarrow{\overrightarrow{0}}$ (Pigman and Rizvi, 1959; Balázs and Sundblad, 1959). This relationship between the concentration and the effect of cysteine may have some connection with the observation that patients with rheumatoid arthritis and other connective tissue diseases have a decreased plasma concentration of free thiol groups (Lorber and Pearson, 1963), since in the present work cysteine administered in high amounts produced an $\frac{3}{3}$ inhibition of the skin "permeability" (Table III).

The prolonged administration of penicillamine, which showed a mild inhibitory effect in the depoly- $-\frac{7}{0}$ merization of hyaluronic acid in vitro in the presence of ascorbic acid (Matsumura and others, in the press), $\mathcal{N}$ did not alter the skin permeability of rats. It $N$ is of interest that the animals treated with penicil- $N$ lamine for 3 weeks had a very brittle skin such as is characteristic of rats with vascular fragility.

The literature covering the effect of corticosteroids $\stackrel{0}{=}$ on skin permeability is controversial, and in addition $\stackrel{\varnothing}{\oplus}$ the permeability effect is known to be closely related to time. For this reason, the effect on connective tissue permeability in rats of a single dose $(0.25 \mathrm{mg}$.) and of prolonged oral treatment with prednisone were $\frac{\Omega}{\mathbb{D}}$ 
examined. Since toxic doses of corticosteroids produce adrenal atrophy (D'Arcy and Howard, 1962), we also examined the weight of adrenals of the rats which were given the drug for 18 days; the ratio weight of adrenals : body weight was $0 \cdot 14$ in these animals as compared with $0 \cdot 17$ for untreated rats of the same age and weight ranges.

Administration of a single dose of prednisone to rats seemed to inhibit skin permeability when measured 120 minutes after administration of the drug, corresponding to a 60 -min. tracing as shown in Fig. 4. The spread areas recorded at subsequent times, 180 and 240 minutes, were still markedly smaller than for untreated rats. These results are in good agreement with those recently reported by Misra and Sapru (1964), who measured the shortterm effect of some corticosteroids on the permeability of synovial membrane by the method of Seifter and Baeder (1955). In contrast, prolonged daily administration of $0.25 \mathrm{mg}$. prednisone for 3 weeks did not inhibit the skin permeability as defined by the spreading method. However, the result of prolonged administration of prednisone on rat skin permeability seems to indicate that the antirheumatic properties of the corticoids are not in accord with their effect on permeability of connective tissue, a conclusion also reached by Ciocci and Cervini (1959).

In contrast, a feature of rheumatoid arthritis seems to be an enhanced permeability of the connective tissue, possibly arising from a depolymerization of the hyaluronic acid of the ground substance.

\section{Summary}

Dermal connective tissue "permeability" was studied in vivo in humans by one method, and in rats by two methods. One method measured the rate of diffusion of intradermally injected Evans blue solution and the other the rate of flow of subdermal saline infusion under constant hydrostatic pressure.

The studies on human subjects showed that in patients afflicted with rheumatoid arthritis the spread of intradermally injected dye solution is much greater than in non-arthritic patients and healthy subjects. A variation with age was also noted.

Some compounds used in the treatment of rheumatoid arthritis were previously found to inhibit the oxidative-reductive depolymerization of hyaluronic acid in vitro. The oral administration of sodium diethyldithicarbamate, thiourea, cysteine, and ethanol, substances found to be strong inhibitors in the in vitro reaction, inhibited the permeability of the skin in rats. Sodium diethyldithiocarbamate was the most active; thiourea, sodium salicylate, and cysteine at high concentration also had marked inhibitory effects. These findings indicate a strong parallelism $\frac{\square}{\omega}$ between the in vitro and in vivo reactions. However, among the anti-rheumatic drugs studied, $\stackrel{\vec{\rho}}{+}$ pencillamine and prednisone administered for 3 O weeks did not modify the "normal" permeability of the skin in rats, although prednisone had a marked $\frac{\bar{m}}{\frac{D}{2}}$ short-term effect.

The results in humans and animals suggest that the state of polymerization of hyaluronic acid may be the principal regulator of permeability phenomena in the ground substance.

\section{REFERENCES}

Balázs, E. A., and Sundblad, L. (1959). Acta Soc. Med. upsalien, 64, 137.

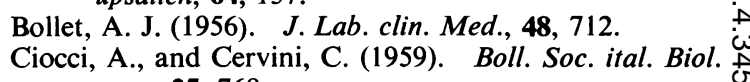
sper., 35, 768.

D'Arcy, P. F., and Howard, E. M. (1962). J. Pharm. 은 Pharmacol., 14, 294.

Decker, B., McKenzie, B. F., McGuckin, W. F., and $\subseteq$ Slocumb, C. H. (1959). Arthr. and Rheum., 2, 162.

Duran-Reynals, F. (1935). J. exp. Med., 61, 617.

(1936). Ann. Inst. Pasteur, 57, 597.

Fabianek, J., Herp, A., and Pigman, W. (1963). Arch. int. Physiol. 71, 647.

$-,-1,-(1965)$. Excerpta Medica Foundation, $\frac{\partial}{\partial}$ International Congress Series, No. 82, pp. 35.

Harris, R., Millard, J. B., and Banerjee, S. K. (1958). Ф Ann. rheum. Dis., 17, 189.

Johansen, P. E., and Sylvest, O. (1961). Acta rheum. scand., 7, 240.

Lenstrup, J. (1951). Acta pharmacol. (Kbh.), 7, 143.

Lorber, A., and Pearson, C. M. (1963). Arthr. and? Rheum., 6, 285.

Matsumura, G., Herp, A., and Pigman, W. Rad. Res. (in the press).

Michelazzi, A. M. (1943). G. clin. Med., 15, 749.

Misra, S. S., and Sapru, H. N. (1964). Indian J. Physiol. Pharmacol., 8, 89.

Pigman, W., Matsumura, G., and Herp, A. (1965). 0 In "Proc. Fourth International Congress on Rheology, Providence, Rhode Island, 1963. Part 4:Symposium on Biorheology", ed. A. L. Copley, p. 505. Interscience, New York.

and Rizvi, S. (1959). Biochem. biophys. Res. Comm., $1,39$.

$-\frac{1,}{4}$, and Holley, H. L. (1961). Arthr. and Rheum., స్ 4, 240.

Platt, D., Holley, H. L., and Pigman, W. (1957). $J_{0}$ Lab. clin. Med., 49, 762.

Ropes, M. W., Bennett, G. A., Cobb, S., Jacox, R., andœ Jessar, R. A., (1957). J. chron. Dis., 5, 630.

Ragan, C., and Meyer, K. (1949). J. clin. Invest., 28, 56.

Scheffé, H. (1959). "The Analysis of Variance", pp. 6672, 75-83, 106-112. Wiley, New York. 
Seifter, J., and Baeder, D. H. (1955). Proc. Soc. exp. Biol. (N.Y.), 87, 276.

Stafford, C. T., Niedermeier, W., Holley, H. L., and Pigman, W. (1964). Ann. rheum. Dis., 23, 152.

Sundblad, L. (1953). Acta Soc. Med. upsalien., 58, 113.

\section{La perméabilité du tissu conjonctif cutané chez les rhumatisants arthritiques}

\section{RÉSUMÉ}

On étudia la "perméabilité" du tissu conjonctif dermique par une méthode chez des sujets humains et par deux méthodes in vivo chez des rats. L'une des méthodes mesura la vitesse de diffusion d'une solution de bleu d'Evans injectée par la voie intradermique, l'autre le débit d'une infusion sous-cutanée d'eau physiologique à pression hydrostatique constante.

Les expériences sur des sujets humains révélèrent que les malades atteints d'arthrite rhumatismale accusent une diffusion plus prononcée de la solution colorante intradermique que les malades non-arthritiques et les sujets sains. On nota aussi un effet de l'âge du sujet.

On savait déjà que certains composés employés dans le traitement de l'arthrite rhumatismale avaient un pouvoir inhibiteur sur la dépolymérisation oxidativo-réductrice de l'acide hyaluronique in vitro. L'administration par voie buccale du diethyldithiocarbamate de soude, de la thiourée, de la cystéine et de l'éthanol, inhibiteurs forts de la réaction in vitro, inhiba aussi la "perméabilité" cutanée chez le rat. Le diethyldithiocarbamate fut le plus actif; la thiourée, le salicylate de soude et la cystéine à haute concentration exercèrent aussi un effet inhibiteur prononcé. Ces résultats indiquent un parallélisme marqué entre les actions in vitro et in vivo. Toutefois, parmi les substances antirhumatismales étudiées, la pénicillamine et la prednisone, administrées pendant trois semaines, ne modifièrent pas la perméabilité "normale" de la peau des rats, bien que la prednisone eusse un effet ephémère prononcé.

Ces résultats chez l'homme et chez l'animal suggèrent que l'état de polymérisation de l'acide hyaluronique joue un rôle majeur dans la régulation des phénomènes de perméabilité dans la matrice.

\section{Permeabilidad del tejido conectivo de la dermis en artritis reumatoide}

\section{Sumario}

Se ha estudiado la "permeabilidad" del tejido conectivo de la dermis usando un método en humanos y dos métodos, in vivo, en ratas. Uno de los métodos midió la tasa de difusión de una solución de azul de Evans inyectada dentro de la dermis y el otro la tasa de flujo de una solución salina inyectada debajo de la dermis bajo presión hidrostatica constante.

Los estudios en sujetos humanos mostraron que en los pacientes con artritis reumatoide la extensión de la solución del colorante inyectada en la dermis estaba grandemente aumentada en comparación con pacientes sin artritis y con sujetos normales. Tambien se observó un efecto relacionado con la edad.

Se ha observado previamente que algunos del os compuestos usados en el tratamiento de la artritis reumatoide inhiben la depolimerización oxidativa-reductora del ácido hialurónico in vitro. Las siguientes substancias: dietilditiocarbamato, tiourea, cisteina y etanol, que se comportan como fuertes inhibidores de la reacción in vitro, inhibieron la "permeabilidad" de la piel en ratas al ser administradas a estas por la boca. El dietilditiocarbamato sódico fué el más activo, la tiourea, el salicilato sódico y la cisteina en concentraciones altas también mostraron efectos inhibidores; estos hallazgos indican un fuerte paralelismo entre las acciones de estas drogas in vitro e in vivo. Sin embargo entre las drogas antirreumáticas estudiadas, la penicilamina y la prednisona administradas durante un período de tres semanas no modificaron la permeabilidad "normal" en la piel de las ratas aunque la prednisona en una sola dosis mostró un marcado efecto inhibidor.

Los resultados en sujetos humanos y en animales sugieren que el estado de polimerizacion del ácido hialurónico puede ser el principal regulador del fenómeno de permeabilidad en la substancia fundamental. 